\title{
PERLINDUNGAN HUKUM KONSUMEN DALAM TRANSAKSI SECARA
}

\section{ONLINE}

\author{
Sukarmi \\ Fakultas Hukum Unissula \\ sukarmi sh@yahoo.com \\ Yudhi Tri Permono \\ Fakultas Hukum Unissula \\ Yudhi tp@gmail.com
}

\begin{abstract}
The purpose of this study are to know the process of online sale and purchase transactions and to find out the problem in online sale transaction and settelment efforts. The approach method used in this research is the normative juridical approach, meaning that legal research is done by examining library materials or secondary data. Data analysis method used is qualitative analysis. From the results of this study it can be concluded 1) the process of buying and selling transactions online (Site Lazada.co.id) include: entry to the site / web shop online, choose the type of goods desired, click the purchase order, make payment transactions, the merchant to send goods 2) problems in online buying and selling transactions and the settlement efforts such as the weakness of the consumer position against the business actors, the validity of the agreement pursuant to Article 1320 Civil Code and no guarantor institution on line. Efforts through the granting of trust by business actors in the website, the consumer can know the business actor is a provider of electronic transactions that can be trusted. The government should increase awareness of consumers to want to report losses due to online transactions
\end{abstract}

Keyword: Consumer, Legal Protection, Online Transactions

\section{A. Pendahuluan}

Dinamika persaingan bisnis dalam perkembangan dunia teknologi informasi yang semakin maju dan pesat dari waktu ke waktu sudah terasa dampaknya oleh sebagian besar masyarakat dari yang sederhana menjadi modern dan serba cepat sehingga berdampak pada 
perilaku informasi dalam segala bidang, baik bidang pendidikan, kesehatan, hiburan, sumber informasi, tenaga kerja, dunia bisnis dan komunikasi tanpa batasan tempat dan waktu, kebutuhan informasi yang lebih cepat dan murah tentunya menuntut para pemberi informasi untuk memiliki sebuah media online, dimana informasi yang disajikan bisa dengan mudah dan cepat didapatkan oleh konsumen informasi. Hal ini dapat dilakukan dengan penggunaan internet. ${ }^{1}$

Teknologi informasi membuka mata dunia akan sebuah dunia baru, Market place baru dan sebuah jaringan bisnis dunia yang tanpa batas. Bagaimanapun juga, teknologi internet berhasil mengubah pola interaksi masyarakat, yaitu interaksi bisnis, ekonomi, sosial dan budaya. Bertolak dari situ internet telah memberi kontribusi yang demikian besar bagi masyarakat, perusahaan/industri maupun pemerintah. Kehadiran internet dianggap dapat menunjang efektivitas dan efisiensi operasional perusahaan terutama perannya sebagai sarana informasi yang dibutuhkan oleh sebuah usaha dan bentuk badan usaha atau lembaga lainnya. ${ }^{2}$ Teknologi internet yang serba digital itu dapat berfungsi sebagai ajang promosi strategis yang efektif dan efisien, karena internet dapat menjangkau seluruh yurisdiksi hukum negara-negara di dunia ${ }^{3}$.

Salah satu perkembangan teknologi internet yang signifikan adalah transaksi jual-beli secara online atau e-commerce. Belanja online pun sudah merupakan hal yang biasa dalam kehidupan masyarakat saat ini. Elektronic commerce atau yang umum dikenal sebagai e-commerce merupakan pembelian dan penjualan produk atau jasa melalui sistem elektronik seperti internet dan jaringan komputer

${ }^{1}$ Shabur Miftah Maulana, Heru Susilo, Riyadi, Implementasi E-Commerce Sebagai Media Penjualan Online (Studi Kasus Pada Toko Pastbrik Kota Malang), Jurnal Administrasi Bisnis, Vol. 29 No. 1 Desember 2015, hlm.1-9

${ }^{2}$ Iman Sjahputra, Perlindungan konsumen dalam Transaksi Elektronik, Alumni, Bandung, 2010, hlm. 13

${ }^{3}$ Ibid., hlm. 2. 
lainnya. Istilah ini dapat mencakup seluruh proses online seperti Penjualan, pengiriman, pelayanan, pemasaran serta pembayaran.Sedangkan Konsumen adalah setiap orang pemakai barang dan/atau jasa yang tersediadalam masyarakat, baik bagi kepentingan diri sendiri, keluarga, orang lain maupun mahkluk hidup lain dan tidak untuk diperdagangkan. ${ }^{4}$

Penggunaan data digital sebagai media untuk membuat suatu perjanjian akan berimplikasi pada efisiensi kinerja perusahaan, terutama bagi perusahaan-perusahaan yang menjalankan aktivitas usahanya lewat jaringan teknologi internet. Namun, perjanjian yang dibuat dalam internet bukan berarti tidak menimbulkan masalah baru. Sejauh dapat diamati, permasalahan itu sangat terkait dengan upaya perlindungan konsumen. Secara teoretis dikatakan bahwa konsumen dapat menggunakan hukum sebagai alat proteksi bila perjanjian dianggap sah dan mengikat para pihak dalam perjanjian. Akibatnya akan muncul satu pertanyaan sejak kapan perjanjian yang dibuat lewat teknologi internet itu dianggap sah dan mengikat para pihak. ${ }^{5}$

Dalam praktiknya, syarat-syarat perjanjian diatur dalam Pasal 1320 KUHPerdata. Menurut ketentuan ini sahnya suatu perjanjian harus memenuhi empat persyaratan utama;

1. Adanya kata sepakat bagi mereka yang mengikatkan dirinya;

2. Adanya kecakapan untuk membuat suatu perjanjian;

3. Harus ada hal tertentu;

4. Harus ada kausa yang halal.

Penting dicatat bahwa setiap transaksi perniagaan elektronik yang memenuhi syarat Pasal 1320 harus diakui sebagai perjanjian yang mengikat para pihak. Oleh karena itu seluruh bentuk perjanjian

${ }^{4}$ Shidarta, Hukum Perlindungan Konsumen Indonesia, Grasindo, Jakarta, 2000, hIm. 1.

${ }^{5}$ Ahmad M. Ramli, Cyber Law dan HAKI dalam Sistem Hukum di Indonesia, Cetakan kesatu, Refika Aditama, Bandung, 2004, hlm. 36. 
yang dibuat secara online memiliki kekuatan hukum berlaku (enforceable) dan mengikat (binding) para pihak dalam perjanjian.

Transaksi perdagangan secara elektronik memiliki resiko yang jauh lebih besar daripada periode tradisional sebelumnya. Bertransaksi atau berbelanja di pasar tradisional/konvensional, ketika seorang konsumen merasa dirugikan atas perbuatan pelaku usaha/penjual, maka konsumen dapat segera melakukan complain, namun ketika seorang konsumen bertransaksi melalui internet, ketika terjadi perbuatan curang oleh pelaku usaha atau penjual, maka biasanya sulit bagi konsumen untuk melakukan complain kepada pelaku usaha atau penjual yang dapat dikarenakan oleh beberapa sebab, misalkan konsumen tidak mengetahui keberadaan pelaku usaha, atau pelaku usaha tidak menerima complain setelah barang di kirimkan atau bahkan ada itikad tidak baik dari pelaku usaha yang mengatakan bahwa uang pembayaran belum diterima pelaku usaha dan lain-lain.

Ketika seorang konsumen mengkonsumsi atau menggunakan suatu produk barang ataupun jasa, maka setiap konsumen pasti menginginkan adanya kepuasan terhadap produk tersebut, minimal konsumen menginginkan adanya informasi yang jelas atas produk yang akan dibeli, keyakinan bahwa produk yang dibeli tidak berbahaya bagi kesehatan dan aman bagi jiwanya, produk yang dibeli cocok dan sesuai dengan keinginannya, baik segi kualitas maupun harga, konsumen tahu cara penggunaannya, ada garansi dari produk yang dibelinya. Namun kenyataan yang muncul seringkali konsumen tidak memperoleh apa yang diharapkannya secara maksimal sehingga akibatnya konsumen merasa dirugikan.

Lemahnya posisi konsumen seringkali dimanfaatkan oleh pelaku usaha untuk memperoleh keuntungan yang sebesar-besarnya dari konsumen. Faktor ketidak tahuan konsumen, tidak jelasnya informasi 
terhadap barang/jasa yang diberikan pelaku usaha, tidak pahamnya konsumen pada mekanisme transaksi menjadi faktor penyebab lemahnya kedudukan konsumen. Oleh karena itu, dalam rangka menciptakan iklim berusaha yang sehat bagi konsumen dalam melakukan transaksi perdagangan melalui e-commerce, maka perlu diupayakan suatu bentuk pengaturan hukum yang baru sekaligus memadai yang mampu mengatur segala aktivitasnya. ${ }^{6}$

Di Indonesia telah diatur Undang-Undang No. 8 tahun 1999 tentang Perlindungan Konsumen (UUPK) yang di dalamnya ada aturan mengenai hak-hak konsumen. Dalam setiap transaksi atau penggunaan suatu produk barang dan jasa tertentu, pelaku usaha harus menjamin semua hak konsumen terpenuhi. Dalam Pasal 17 UUPK juga diatur tentang larangan pelaku usaha memproduksi iklan yang mengelabui konsumen mengenai kualitas, kuantitas, bahan, kegunaan dan harga barang dan/atau tarif jasa serta ketepatan waktu penerimaan barang dan/atau jasa. Pelaku usaha juga dilarang mengelabui jaminan/garansi terhadap barang dan/atau jasa, serta pelaku usaha dilarang memuat informasi yang keliru, salah, atau tidak tepat mengenai barang dan/atau jasa.

Selain itu juga diatur Undang-Undang No. 19 tahun 2016 tentang perubahan atas Undang-Undang No. 11 tahun 2008 tentang Informasi dan Transaksi Elektronik (UU ITE). Di dalam Pasal 9 UU ITE ini disebutkan bahwa pelaku usaha yang menawarkan produk melalui Sistem Elektronik harus menyediakan informasi yang lengkap dan benar berkaitan dengan syarat kontrak, produsen dan produk yang ditawarkan. Dalam hal ini informasi yang dibuat oleh pelaku usaha untuk menarik konsumen harus benar-benar sesuai dengan barang / jasa yang ditawarkannya agar tidak memunculkan ekspektasi yang

${ }^{6}$ Elisatris Gultom, Perlindungan Konsumen Dalam Transaksi E-Commerce, Dalam Cyber law : Suatu Pengantar, Elips, Bandung, 2002, hlm. 55. 
berbeda dari pihak konsumen.

Pada umumnya kerugian yang sering dialami oleh konsumen adalah tidak mendapatkan barang sesuai informasi yang diberikan oleh pelaku usaha sebelumnya, dan tidak sedikit konsumen memilih untuk pasrah dan tidak berusaha untuk memperjuangkan hak-haknya yang telah dirugikan oleh pihak pelaku usaha dalam transaksi elektronik.

\section{B. METODE PENELITIAN}

Metode pendekatan yang digunakan dalam penelitian ini adalah pendekatan yuridis normatif, artinya penelitian hukum ini dilakukan dengan cara meneliti bahan pustaka atau data sekunder belaka, yang dalam hal ini berkaitan dengan perlindungan hukum terhadap konsumen dalam transaksi jual beli secara online

\section{HASIL PENELITIAN DAN PEMBAHASAN}

\section{Proses Transaksi Jual-Beli Secara Online}

Transaksi jual beli online (E-commerce) merupakan metode penjualan yang sedang berkembang pesat seiring perkembangan teknologi di zaman sekarang ini. Penjualan online memudahkan kita mencari barang yang kita inginkan dengan cepat dan tentunya tidak menghabiskan banyak waktu dan energi karena yang kita butuhkan untuk mencari hanya komputer serta koneksi internet. Kita tidak perlu berjalan mengunjungi setiap toko yang menjual barang yang di inginkan, dengan begitu kita dapat menghemat waktu serta biaya untuk mencari suatu barang sehingga lebih efektif dan efisien. Penjualan online sangat menguntungkan kedua belah pihak, antara penjual dan pembeli. Untuk penjual, produk atau tokonya dapat tersebar luas di internet sehingga informasi tentang produknya dapat diketahui dan dilihat oleh calon pembeli. Sedangkan bagi pembeli, dapat melihat berbagai macam produk yang dicari dan dijual di internet serta dapat membandingkan suatu 
produk dengan produk lainnya dengan cepat. Salah satu website yang memfasilitasi jual beli online adalah lazada.co.id.

Secara singkat E-Commerce dapat dipahami sebagai jenis transaksi perdagangan baik barang maupun jasa lewat media elektronik. Dalam usaha bidang operasionalnya E-Commerce ini dapat berbentuk B to B (Business to Business/Bisnis untuk Bisnis) atau $\mathrm{B}$ to $\mathrm{C}$ (Business to Consumers/Bisnis untuk Konsumen). Khusus untuk $B$ to $C$ pada umumnya posisi konsumen tidak sekuat perusahaan sehingga dapat menimbulkan beberapa persoalan. Oleh karena itu para konsumen harus berhati-hati dalam melakukan transaksi lewat internet. Persoalan tersebut antara lain menyangkut masalah mekanisme pembayaran (payment mechanism) dan jaminan keamanan dalam bertransaksi (security risk). ${ }^{7}$

Cara berbelanja online pada situs Lazada.co.id adalah sebagai berikut:

1. Untuk belanja Online di lazada langkah pertama adalah masuk ke situs/web lazada yaitu www.lazada.co.id. Setelah itu pengguna dapat memilih barang apa yang hendak dibeli seperti fashion, tas, jam tangan, handphone/Hp, tablet, elektronik, peralatan rumah tanggadan lain-lain.

2. Kemudian langkah selanjutnya klik "BELI SEKARANG" dan sudah otomatis masuk ke troli kranjang pembelian pengguna

3. Setelah pengguna mengklik "Beli Sekarang" di langkah 2, maka otomatis keluar Pop Up untuk mengkonfirmasi pembelian dengan cara klik "Konfirmasi"

4. Jika pengguna sudah mengkonfirmasi di langkah 3 Selanjutnya masukkan email pengguna yang masih aktif. Apabila pengguna

7 Lathifah Hanim, Perlindungan Hukum Bagi Para Pihak Dalam E-Commerce Sebagai Akibat Dari Globalisasi Ekonomi, Jurnal Pembaharuan Hukum, Volume I No. 2 Mei-Agustus 2014, hlm.191-199 
baru pertama kali belanja online di Lazada maka harus mendaftar terlebih dahulu dengan mengisi kolom yang sudah tersedia yang terdiri dari :.
a. Kolom 1. Nama Lengkap Pengguna
b. Kolom 2. Alamat lengkap sesuai KTP
c. Kolom 3. Provinsi
d. Kolom 4. Kota
e. Kolom 5. Kecamatan
f. Kolom 6. No Handphone

5. Langkah terakhir pengguna tinggal memilih metode pembyaran ke lazada. Ada 7 opsi pembayaran yang disediakan oleh pihak lazada. Berikut penjelasan mengenai metode pembayaran di lazada :

1. Bayar di Tempat/COD

Pembayaran dilakukan secara tunai menggunakan uang cash setelah barang sudah sampai di tempat dan tidak di pungut biaya dan pajak sama sekali.

2. Kartu kredit/debit

Pengguna tinggal mengisikan nomor kartu, nama sesuai kartu dan tanggal kadaluarsa CCV/CW.

3. Bank Transfer

Selanjutnya adalah mengkonfirmasi pembayaran dengan mengupload bukti pembayaran .

4. Helopay

Pembayaran dengan visa, indomaret dan bisa transfer dari semua bank melalui jaringan ATM bersama.PRIMA dan Alto.

5. BCA Klickpay

Nanti akan di alihkan ke halaman BCA Klickpay untuk konfirmasi pesanan pengguna 
6. MANDIRI Klickpay

Memiliki user ID Mandiri klickpay dan token Mandiri. Pengguna hanya memasukan no kartu dan pastinya pengguna sudah terdaftar di Mandiri klickpay

7. Cicilan online

Daftar Bank untuk cicilan yang di dukung adalah menggunakan kartu kredit mandiri dan BNI, untuk opsi angsuran dari mulai 3 bulan, 6 bulan dan 12 bulan

Transaksi e-commerce antara pihak e-merchant (pihak yang menawarkan barang atau jasa melalui internet) dengan e-customer (pihak yang membeli barang atau jasa melalui internet) yang terjadi di dunia maya atau di internet pada umumnya berlangsung secara paperless transaction, sedangkan dokumen yang digunakan dalam transaksi tersebut bukanlah paper document, melainkan dokumen elektronik (digital document).

Secara umum tahapan mekanisme transaksi e-commerce dapat diurutkan sebagai berikut:

1. E-customer /pihak yang membeli barang atau jasa melalui internet dan E-merchant /pihak yang menawarkan barang atau jasa melalui internet bertemu dalam dunia maya melalui server yang disewa dari Internet Server Provider (ISP) oleh emerchant.

2. Transaksi melalui e-commerce disertai term of use dan sales term condition atau klausula standar, yang pada umumnya $e$ merchant telah meletakkan klausula kesepakatan pada websitenya, sedangkan e-customer jika berminat tinggal memilih tombol accept atau menerima. 
3. Penerimaan e-customer melalui mekanisme "klik" tersebut sebagai perwujudan dari kesepakatan yang tentunya mengikat pihak e-merchant

4. Pada saat kedua belah pihak mencapai kesepakatan, kemudian diikuti dengan proses pembayaran, yang melibatkan dua bank perantara dari masing-masing pihak yaitu acquiring merchant bank dan issuing customer bank.Prosedurnya e-customer memerintahkan kepada issuing customer bank untuk dan atas nama e-customer melakukan sejumlah pembayaran atas harga barang kepada acquiring merchant bank yang ditujukan kepada e-merchant.

5. Setelah proses pembayaran selesai kemudian diikuti dengan proses pemenuhan prestasi oleh pihak e-merchant berupa pengiriman barang sesuai dengan kesepakatan mengenai saat penyerahan dan spesifikasi barang.

Menurut Onno w.Purbo dan Aang Arif wahyudi ada lima tahapan dalam melakukan transaksi e-commerce, kelima tahapan itu adalah 8

\section{Find it}

Pada tahap ini pembeli bisa mengetahui dengan pasti dan mudah jenis barang apa yang diinginkan. Ada beberapa metode yang dapat dilakukan yaitu dengan metode search dan browse. Dengan search, pembeli bisa mendapatkan tipe - tipe barang yang diinginkan dengan hanya memasukkan keywords (kata kunci) barang yang diinginkan pada kotak search. Sedangkan browse menyediakan menu-menu yang terdiri atas jenis-jenis barang yang disediakan.

\section{Explore it}

8 Onno w.Purbo dan Aang Arif Wahyudi, Mengenal e-Commerce, Elex Media Komputindo, Jakarta, 2001, hlm. 143. 
Setelah memilih jenis barang tertentu yang diinginkan, maka akan dijumpai keterangan lebih jelas mengenai barang yang dipilih itu antara lain terdiri dari informasi penting tentang produk tersebut seperti harga dan gambar barang tersebut, nilai rating barang itu yang diisi oleh para pembeli sebelumnya apakah barang tersebut baik, cukup baik atau bahkan mengecewakan, spesifikasi (product review) tentang barang tersebut dan menu produk - produk lain yang berhubungan. Jika ternyata barang yang dilihat tersebut sudah cocok, maka siap untuk melakukan transaksi.

3. Select it

Seperti halnya toko yang sebenarnya, shopping cart akan menyimpan terlebih dahulu barang yang diinginkan sampai pada check out. Shopping cart software adalah perangkat lunak yang digunakan dalam e-commerce untuk membantu orang membuat pembelian secara online. Perangkat lunak ini memungkinkan pelanggan belanja online untuk mengumpulkan daftar item untuk pembelian atau bisa disebut "menempatkan item dalam keranjang belanja". Selain itu shopping cart juga dapat menghapus atau menyimpan daftar belanja untuk keperluan nanti. Setelah checkout, perangkat lunak biasanya menghitung total pesanan, termasuk pengiriman dan penanganan yaitu ongkos kirim dan pengepakan, biaya dan pajak yang terkait.

4. Buy it

Setelah semua yang diatas dilakukan, selanjutnya dilakukan proses check out. Pada tahap ini, dilakukan proses transaksi pembayaran setelah terlebih dahulu mengisi formulir yang telah disediakan oleh merchant. Pihak merchant tidak 
akan menarik pembayaran pada credit card sampai kita sudah menyelesaikan proses perintah untuk pengiriman.

\section{Ship it}

Setelah proses transaksi selesai, pihak merchant akan mengirimkan e-mail konfirmasi pembelian dan e-mail lain yang akan memberitahukan pengiriman barang telah dilakukan. Toko online juga menyediakan account untuk para pelanggan mereka seperti halnya ketika akan memasuki mailbox pada layanan fasilitas e-mail gratis. Sehingga pembeli dapat mengetahui status order pada account yang telah tersedia di situs tersebut.

Suatu transaksi e-commerce juga merupakan suatu perjanjian jual beli yang sama dengan jual beli konvensional pada umumnya. Di dalam suatu transaksi e-commerce juga mengandung suatu asas konsensualisme, yang berarti kesepakatan dari kedua belah pihak. Suatu kesepakatan terjadi apabila terdapat suatu penawaran dari pihak penjual lalu ada suatu penerimaan dari pihak calon pembeli. Penawaran dan penerimaan inilah yang merupakan awal terjadinya kesepakatan antara pihak-pihak yang bersangkutan.

Menurut Mieke Komar Kantaatmadja, mengenai kapan terjadinya kesepakatan terdapat beberapa teori, antara lain $:^{9}$

1. Teori ucapan

Suatu perjanjian tercapai pada saat orang menerima tawaran dan menyetujui tawaran tersebut.

2. Teori pengiriman

Perjanjian tercapai pada saat dikirimkannya surat jawaban mengenai penerimaan terhadap suatu penawaran.

3. Teori pengetahuan

${ }_{9}^{9}$ Mieke Komar Kantaatmadja, Cyberlaw : Suatu Pengantar,cet.1, Elips, Bandung, 2001, hlm. 31 
Menurut teori ini, bahwa perjanjian tercapai setelah orang yang menawarkan mengetahui bahwa penawarannya telah disetujui.

4. Teori penerimaan

Menyatakan perjanjian tercapai saat diterimanya surat jawaban penerimaan oleh orang yang menawarkan

Sedangkan proses transaksi online dalam pandangan islam dikenal dengan istilah $\mathrm{Ba}^{\prime} \mathrm{i}$ as-salam atau disebut juga as-salaf merupakan istilah dalam bahasa Arab yang mengandung makna penyerahan. Lebih lanjut as-salam merupakan transaksi atas sesuatu yang masih berada dalam tanggungan dengan kriteriakriteria tertentu dan diserahkan kemudian dengan pembayaran harga di tempat kontrak atau secara lebih ringkas disebutkan jual beli yang ditangguhkan dengan harga disegerakan.

Transaksi as-salam merupakan bagian dari transaksi jual beli biasa. Hanya saja dalam transaksi as-salam terdapat persyaratan tambahan yang menentukan validitas transaksi tersebut. Karena dalam transaksi as-salam produk yang dijadikan obyek transaksi tidak ada / tidak dapat dihadirkan pada saat transaksi terjadi. Penjual dalam hal ini hanya menyebutkan kriteriakriteria tertentu pada produk yang akan dijual. Seperti halnya jual beli biasa transaksi as-salam memiliki unsur-unsur yang harus ada dan saling berhubungan ketika terjadinya suatu transaksi jual beli. Unsur-unsur yang dimaksudkan merupakan tiga unsur rukun termasuk pihak-pihak yang terlibat dalam transaksi as-salam, yaitu pertama tentang sighat transaksi (ijab qabu), kedua tentang pelaku transaksi (ba'i dan mustari) dan ketiga tentang obyek transaksi (Ma'qus alaih).

\section{Masalah dalam Transaksi Jual Beli Secara Online dan Upaya} Penyelesaiannya 
Berikut penulis jabarkan berbagai masalah seputar e-commerce dan upaya penyelesaiannya :

1. Lemahnya kedudukan konsumen terhadap pelaku usaha

Pada dasarnya suatu perjanjian dibuat berdasarkan negosiasi oleh para pihak, tetapi dengan penggunaan klausula baku, isi perjanjian telah ditentukan secara sepihak oleh pelaku usaha. Konsumen tidak memiliki posisi tawar (bergaining position) yang seimbang dengan pelaku usaha. Penggunaan klausula baku dalam perjanjian jual-beli memang secara Hukum Perdata diakui sah karena tidak adanya unsur pemaksaan kehendak didalamnya yakni jika konsumen menyetujui, maka ia sudah tahu mengenai segala resiko yang akan ditanggungnya, namun jika ia menolak klausula baku maka para pengusaha tidak akan memaksanya.

Praktiknya konsumen demi memenuhi kebutuhan hidupnya tidak jarang juga menyetujui klausula baku yang telah terlebih dahulu ditetapkan oleh pengusaha. Melihat kondisi demikian, acap kali pengusaha membuat isi klausula baku cenderung menguntungkan diri sendiri sehingga timbullah ketidakseimbangan hak dan kewajiban antara pengusaha dengan konsumen.

Berdasarkan kondisi yang tidak seimbang ini pemerintah memberikan perlindungan kepada konsumen dari tindakan sewenang-wenang dari pengusaha terkait pemakaian klausula baku dalam setiap perjanjian jual beli. Dalam hal ini pemerintah mengatur mengenai ketentuan apa saja yang boleh dimasukkan kedalam kausula baku dan hal yang dilarang untuk dicantumkan, dengan tujuan agar konsumen tidak diugikan. Pengaturan mengenai kausula baku tersebut diatur dalam Pasal 
18 UUPK yang menyatakan sebagai berikut :

(1) Pelaku usaha dalam menawarkan barang dan/atau jasa yang ditujukan untuk diperdagangkan dilarang membuat atau mencantumkan klausula baku pada setiap dokumen dan/atau perjanjian apabila:

a. menyatakan pengalihan tanggung jawab pelaku usaha

b. menyatakan bahwa pelaku usaha berhak menolak penyerahan kembali barang yang dibeli konsumen;

c. menyatakan bahwa pelaku usaha berhak menolak penyerahan kembali uang yang dibayarkan atas barang dan/atau jasa yang dibeli oleh konsumen;

d. menyatakan pemberian kuasa dari konsumen kepada pelaku usaha baik secara langsung maupun tidak langsung untuk melakukan segala tindakan sepihak yang berkaitan dengan barang yang dibeli oleh konsumen secara angsuran;

e. mengatur perihal pembuktian atas hilangnya kegunaan barang atau pemanfaatan jasa yang dibeli oleh konsumen;

f. memberi hak kepada pelaku usaha untuk mengurangi manfaat jasa atau mengurangi harta kekayaan konsumen yang menjadi obyek jual beli jasa;

g. menyatakan tunduknya konsumen kepada peraturan yang berupa aturan baru, tambahan, lanjutan dan/atau pengubahan lanjutan yang dibuat sepihak oleh pelaku usaha dalam masa konsumen memanfaatkan jasa yang dibelinya;

h. menyatakan bahwa konsumen memberi kuasa kepada pelaku usaha untuk pembebanan hak tanggungan, hak 
gadai, atau hak jaminan terhadap barang yang dibeli oleh konsumen secara angsuran.

(2) Pelaku usaha dilarang mencantumkan klausula baku yang letak atau bentuknya sulit terlihat atau tidak dapat dibaca secara jelas, atau yang pengungkapannya sulit dimengerti.

(3) Setiap klausula baku yang telah ditetapkan oleh pelaku usaha pada dokumen atau perjanjian yang memenuhi ketentuan sebagaimana dimaksud pada ayat (1) dan ayat (2) dinyatakan batal demi hukum.

(4) Pelaku usaha wajib menyesuaikan klausula baku yang bertentangan dengan Undang Undang ini.

2. Keabsahan perjanjian menurut Pasal $1320 \mathrm{KUH}$ Perdata

Disebutkan ada 4 syarat sahnya suatu perjanjian yaitu :

a. kesepakatan antara kedua belah pihak untuk mengikatkan diri,

b. kecakapan untuk membuat perjanjian,

c. suatu hal tertentu, dan

d. suatu sebab yang halal.

E-commerce merupakan metode perdagangan modern yang tidak mempertemukan penjual dan pembeli, maka untuk terjadinya suatu kesepakatan sulit untuk diketahui dengan jelas kapan kesepakatan antara kedua belah pihak itu terjadi. Selain itu mengenai kecakapan kedua belah pihak juga dipertanyakan karena antara penjual dan pembeli tidak bertemu langsung maka tidak dapat diketahui dengan jelas kedua belah pihak tersebut cakap atau tidak menurut Undang-Undang.

Perjanjian elektronik dalam transaksi elektronik harus memiliki kekuatan hukum yang sama dengan kontrak 
konvensional. Sebagaimana ditentukan pada Pasal 18 ayat (1) UUITE yang berbunyi "Transaksi Elektronik yang dituangkan kedalam Kontrak Elektronik mengikat para pihak". Pasal 19 UUITE menyatakan bahwa "para pihak yang melakukan transaksi elektronik harus menggunakan sistem elektronik yang disepakati". Jadi, sebelum melakukan transaksi elektronik, para pihak harus bersepakat untuk menggunakan sistem elektronik untuk melakukan transaksi. Selain itu pelaku usaha dalam websitenya harus mencantumkan kategori umur untuk memasuki website tersebut atau didalam registrasi data pribadi konsumen dicantumkan seperti nomor KTP atau paspor dimana diharapkan dapat menjamin kecakapan seorang konsumen dalam bertansaksi.

Mengenai suatu sebab yang halal juga menjadi permasalahan dalam transaksi jual beli melalui internet. Sebab yang halal dalam Undang-Undang adalah tidak melanggar kesusilaan dan ketertiban umum. Masalahnya barang yang diperdagangkan di internet beraneka ragam dan ada barang disuatu Negara yang diperdagangkan tetapi disuatu Negara tertentu juga ada barang yang tidak boleh diperdagangkan. Sehingga perlu ada peraturan yang melarang memperdagangkan barang-barang yang sesuai dengan aturan hukum positif di Indonesia atau mengadakan perjanjian antar Negara mengenai barang-barang yang boleh diperdagangkan di dunia maya.

3. Tidak ada lembaga penjamin keabsahan toko online

Perusahaan atau akun jual beli online di dunia maya sangatlah mudah untuk didirikan dibandingkan dengan mendirikan perusahaan di dunia nyata. Sebagaimana 
kenyataannya bahwa pendirian suatu perusahaan di dunia nyata memerlukan ijin dari pejabat/ instansi terkait. Namun dalam mendirikan atau membangun toko online di dunia maya hanya menyewa tempat di dunia maya dan membuat web desain toko online pada Internet Service Provider (ISP) maka toko online ini sudah dapat beroperasi layaknya toko di dunia nyata. Kemudahan dalam membuat toko online inilah yang menjadi masalah bagi konsumen yang akan membeli produk pada toko online tersebut. Maraknya kasus penipuan terhadap konsumen seperti misalnya toko online yang fiktif, pencurian nomor kartu kredit dan sebagainya.

Salah satu upaya untuk menutupi kekurangan dalam perlindungan bagi konsumen ini adalah pemberian trustmark oleh pelaku usaha dalam websitenya yang dapat dilihat oleh konsumen. Melalui trustmark tersebut konsumen dapat megetahui bahwa pelaku usaha tersebut merupakan penyelenggara transaksi elektronik yang dapat dipercaya dan mendapat sertifikasi dari lembaga setifikasi yang berwenang, indpenden, dan profesional. Definisi lembaga Sertifikasi Keandalan yang diberikan oleh UU ITE adalah lembaga independen yang dibentuk oleh profesional yang diakui, disahkan, dan diawasi oleh pemerintah dengan kewenangan mengaudit dan mengeluarkan sertifikat keandalan dalam transaksi elektronik.

Dalam hal ini, Pasal 10 ayat (1) UU ITE menentukan bahwa setiap pelaku usaha yang menyelenggarakan transaksi elektronik dapat disertifikasi oleh Lembaga Sertifikasi Keandalan. Dalam penjelasan Pasal ini sertifikasi keandalan dimaksudkan sebagai bukti bahwa pelaku usaha yang 
melakukan perdagangan secara elektronik layak berusaha setelah melalui penilaian dan audit dari badan yang berwenang. Bukti telah dilakukan sertifikasi keandalan ditunjukkan dengan adanya logo sertifikasi berupa trustmark pada laman (home page) pelaku usaha.

4. Masalah keamanan transaksi terkait dengan jaminan kepastian hukum

Implikasi dari pengembangan jual beli online ini dirasa ada sisi positif dan sisi negatif. Aspek positifnya bahwa dengan adanya perdagangan di internet melalui jaringan online dapat meningkatkan peran dan fungsi perdagangan sekaligus memberikan efek efisiensi. Aspek negatifnya adalah persoalan keamanan dalam transaksi menggunakan media e-commerce dan secara yuridis terkait pula dengan jaminan kepastian hukum. Masalah keamanan yang dipermasalahkan dalam aspek ini adalah masalah kerahasiaan pesan, masalah bagaimana cara agar pesan yang dikirimkan itu keutuhannya sampai ke tangan penerima, masalah keabsahan pelaku transaksi dan masalah keaslian pesan agar bisa dijadikan barang bukti.

Untuk menjaga keamanan dan kerahasiaan pesan, data, atau informasi dalam suatu transaksi elektronik diperlukan beberapa enkripsi guna membuat pesan, data, atau informasi agar tidak dapat dibaca atau dimengerti oleh sembarang orang, kecuali untuk penerima yang berhak. Selain itu, dalam konteks perlindungan konsumen dalam transaksi e-commerce, maka pelaku usaha perlu juga menunjukkan bukti keandalan dari sistem elektronik yang dimilikinya dalam melakukan transaksi ecommerce. Sistem pengamanan terhadap transaksi elektronik harus dapat memberikan perlindungan terhadap hal-hal 
berikut:

a. Mengenkripsi atau mengkode pesan, data, atau informasi selama transaksi berlangsung. Ini berarti dapat mengubah informasi ke dalam kode yang hanya dapat dibaca jika orang lain memiliki kuncinya

b. Melindungi pesan, data, atau informasi selama transaksi berlangsung dari pengubahan, penambahan, atau perusakan oleh pihak yang tidak bertanggung jawab.

c. Memverifikasi para pihak yang memang berkepentingan dalam transaksi tersebut dan melindungi dari pihak yang tidak bertanggung jawab atas usaha untuk memperoleh informasi yang dirahasiakan.

5. Keberadaan konsumen yang tidak tervisual secara jelas

Mengingat adanya transaksi yang dilakukan dalam dunia maya, sehingga dapat kemungkinan seperti pihak yang melakukan transaksi mungkin saja pihak yang secara hukum tidak diperkenankan melakukan tindakan hukum. Contohnya pihak konsumen yang melakukan transaksi berusia di bawah ketentuan yang tercantum dalam syarat-syarat dalam melakukan transaksi, ataupun apabila telah terjadi kata sepakat oleh kedua belah pihak dan ketika akan ditelusuri pihak konsumen fiktif. Di dalam perjanjian secara elektronik para pihak dalam melakukan perjanjian tidak memerlukan tatap muka secara langsung, para pihak dalam melaksanakan perjanjian tidak akan bertemu sebelum perjanjian atau bahkan tidak akan pernakh bertemu. Untuk mengatasi resiko perihal ketiadaan tatap muka langsung ini, telah ada mekanisme pengesahan identitas. Teknologi yang dapat diandalkan dalam mekanisme pengesahan identitas adalah teknologi 
penandatanganan secara digital.

Apabila kita menulis sebuah surat biasanya kita menandatangani surat tersebut. Kita melakukan itu dengan tujuan untuk menunjukkan bahwa surat itu otentik, surat itu memang buatan kita. Tanda tangan digital juga bertujuan sama dengan tanda tangan biasa, bedanya proses penandatanganannya juga bersifatl digital. Proses pendaftaran, verifikasi dan penerbitan Tanda Tangan Digital akan difasilitasi melalui platform Sistem Verifikasi Online (SiVION) yang saat ini sudah bisa diakses melalui sivion.id.

6. Yurisdiksi hukum dalam Transaksi jual beli lintas negara

Transaksi yang bersifat lintas batas negara borderless, menimbulkan pertanyaan mengenai yurisdiksi hukum negara mana yang sepatutnya diberlakukan. Klausula mengenai pilihan hukum pada umumnya terjadi pada ecommerce yang bersifat lintas batas Negara. Pilihan hukum menyangkut hukum negara mana yang akan digunakan bila terjadi sengketa, dalam hal ini sengketa antara konsumen dan pelaku usaha yang berkedudukan di luar negeri.

UUPK memiliki kelemahan, yakni tidak dapat menjangkau pelaku usaha yang berkedudukan di luar negeri. Hal ini terlihat dalam rumusan Pasal 1 butir 3 UUPK yang menyatakan :

"Pelaku usaha adalah setiap orang perorangan atau badan usaha, baik yang didirikan dan berkedudukan atau melakukan kegiatan dalam wilayah hukum negara Republik Indonesia, baik sendiri maupun bersama-sama melalui perjanjian penyelenggaraan kegiatan usaha dalam berbagai bidang ekonomi".

Berdasarkan pengertian pelaku usaha di atas maka ruang 
lingkup dari UUPK hanyalah pelaku usaha yang bergerak di dalam wilayah hukum Republik Indonesia. UU ITE sudah mengatur perihal mengenai pilihan hukum yakni dicantumkan dalam Pasal 18 ayat (2) dimana disebutkan bahwa para pihak mempunyai kewenangan untuk memilih hukum yang berlaku bagi transaksi elektronik internasional yang dibuatnya, namun UU ITE tidak mengatur perihal mengenai klausula baku sebagaimana diatur oleh UUPK, sehingga mau tidak mau konsumen tunduk pada ketentuan yang dikeluarkan oleh pelaku usaha.

Walaupun Pasal 18 ayat (2) UU ITE mempunyai kelemahan sebagaimana disebutkan diatas namun terdapat ketentuan internasional yang dapat digunakan untuk memberikan perlindungan kepada konsumen dalam $e$ commerce internasional. Ketentuan tersebut terdapat dalam Konvensi Roma 1980 Pasal 5 ayat (2) yang menegaskan bahwa: "Dalam kontrak bisnis-konsumen, pilihan hukum yang dibuat di dalam kontrak tidak dapat menghilangkan hak-hak konsumen atas perlindungan konsumen dari Negara tempat ia memiliki kediaman tetap".

Sejalan dengan ketentuan yang terkandung dalam konvensi roma 1980 tersebut, berlaku asas bahwa hukum yang dipilih para pihak dalam kontrak tidak dapat mengesampingkan kaidah-kaidah memaksa (mandatory laws) dari Negara yang memiliki closest connection atau koneksi terdekat dengan kontrak. Dengan adanya ketentuan ini walaupun pihak konsumen menggugat pelaku usaha di Negara lain, konsumen tersebut tetap mendapatkan hak-haknya sebagai konsumen 
sebagaimana diberikan oleh UUPK. ${ }^{10}$

\section{PENUTUP}

\section{Kesimpulan}

Proses transaksi jual-beli secara online (E-commerce) terdiri dari Masuk ke situs/web toko online, Setelah memilih jenis barang yang diinginkan, kemudian pilih perintah pembelian yang disediakan oleh merchant, E-customer melakukan transaksi pembayaran setelah terlebih dahulu mengisi formulir yang telah disediakan oleh merchant, Setelah proses pembayaran selesai, pihak merchant melakukan pengiriman barang. Masalah dalam Transaksi Jual Beli Secara Online dan Upaya Penyelesaiannya yaitu Lemahnya kedudukan konsumen terhadap pelaku usaha, Keabsahan perjanjian menurut Pasal 1320 KUH Perdata, Tidak ada lembaga penjamin keabsahan toko online (4) Masalah keamanan transaksi terkait dengan jaminan kepastian hukum (5) Keberadaan konsumen yang tidak tervisual secara jelas (6) Yurisdiksi hukum dalam Transaksi jual beli lintas negara.

\section{Saran}

Pemerintah perlu meningkatkan kesadaran konsumen untuk mau melaporkan atau mengajukan gugatan Konsumen yang mengalami kerugian akibat transaksi jual beli online sangatlah banyak. Namun seringkali tidak dilaporkan ke pihak berwenang karena nilai transaksinya dianggap tidak terlalu besar. Padahal beberapa masuk ranah pidana, seperti kasus penipuan. UndangUndang Perlindungan Konsumen sudah tidak relevan dengan perkembangan zaman. 


\section{DAFTAR PUSTAKA}

\section{A. Buku}

Ahmad M. Ramli, Cyber Law dan HAKI dalam Sistem Hukum di Indonesia, Cetakan kesatu, Refika Aditama, Bandung, 2004;

Elisatris Gultom, Perlindungan Konsumen Dalam Transaksi ECommerce, Dalam Cyber law : Suatu Pengantar, Elips, Bandung, 2002;

Iman Sjahputra, Perlindungan konsumen dalam Transaksi Elektronik, Alumni, Bandung, 2010;

Lathifah Hanim, Perlindungan Hukum Bagi Para Pihak Dalam ECommerce Sebagai Akibat Dari Globalisasi Ekonomi, Jurnal Pembaharuan Hukum, Volume I No. 2 MeiAgustus 2014;

Mieke Komar Kantaatmadja, Cyberlaw : Suatu Pengantar,cet.1, Elips, Bandung, 2001;

Onno w.Purbo dan Aang Arif Wahyudi, Mengenal e-Commerce, Elex Media Komputindo, Jakarta, 2001;

Shabur Miftah Maulana, Heru Susilo, Riyadi, Implementasi ECommerce Sebagai Media Penjualan Online (Studi Kasus Pada Toko Pastbrik Kota Malang), Jurnal Administrasi Bisnis , Vol. 29 No. 1 Desember 2015;

Shidarta, Hukum Perlindungan Konsumen Indonesia, Grasindo, Jakarta, 2000;

\section{B. Perundang - Undangan}

Undang-Undang Republik Indonesia Nomor 8 Tahun 1999 tentang Perlindungan Konsumen 